\title{
MYIASIS, ITS TYPES, CAUSES, AND THE RELATIONSHIP OF SOME BACTERIAL SPECIES TO ITS EVENTS / (ARTICLE REVIEW)
}

\author{
Aulfat T. Yaseen ${ }^{1} \quad$ Dalia A. Mohammed ${ }^{2} \quad$ Eman M. T. Aziz $^{3}$ \\ 1,2,3 Department of Biology / College of Science / University of Mosul \\ Email: aulfat.tahseen@yahoo.com
}

\begin{abstract}
Myiasis is one of the most complex and interesting relationships that we see in nature, as it represents the relationship between small larvae of the order of Diptera and other creatures such as humans and animals. It is also considered an economic problem that causes heavy losses in livestock. And in both animals, where these larvae belong to three families 1. Oestridae 2. Sarcophagidae 3. Calliphoridae, feed on live and dead tissues, it has also been shown that wounds contaminated with bacteria, Streptococcus spp. Staphylococcus aureus ، Klebsiella peneumonia, ‘Pseudomonas spp.، Enterobacter spp. groteus mirabilis are more likely to suffer from myiasis due to their ability to produce volatile organic compounds that are considered as stimuli for flies. Therefore, Artiana, in this scientific article, dealt with a brief and comprehensive review of myiasis, including the classification of its types, the classification of the larvae that cause it, and the bacterial infections associated with myiasis.
\end{abstract}

Key words: Myiasis, Medical insects, Diptera, Larvae, Bacteria

Received: 22 / 1/2021, Accepted: 28 / 2 /2021

\section{INTRODUCTION}

The relationships between living things in nature are very complex. Important observations and constant observation allow us to understand this complexity. One of these relationships is the relationship between flies and backbones animals, and this relationship is either beneficial or harmful (Hall and Wall, 1995). In 1815 Kirby and Spence used the term scholechiasis to describe diseases caused by insect larvae to animals, then in 1840 Hope developed a new term, Maiasis, which means fly larvae invade human and animals body. While the terms scholechiasis and canthariasis were attributed to diseases caused by the insect orders Lepidoptera and Coleoptera respectively (Hall and Wall, 1995). The term myiasis was derived from the Latin word muia flies, which means disease (Sharma et al., 2008), that affects humans and animals as a result of the invasion by Diptera larvae of the living and dead tissues of humans and bodies Liquid (Braverman et al., 1994). Myiasis is a neglected disease that has major economic impacts on animals and humans ((Hall and Wall, 2016). The myiasis flies distributed in the tropics and arctic regions since ancient times until the present day, wide spread indicates the presence of a hosts variety from wild and domestic animals and even humans (Hassona et al., 2014). The wounds resulting from a crack in the skin are accompanied by sores, abscesses, warts, and inflamed skin lesion (Luseba et al., 2007). These wounds and sores on the skin are subject to infection, whether bacterial, 
fungal or other organisms. It has been shown that wounds contaminated with bacteria are more likely to cause melanosis (Sotiraki et al., 2010). The wounds resulting from a crack in the skin are accompanied by sores, abscesses, warts, and inflamed skin lesions (Luseba et al., 2007). These wounds and sores on the skin are subject to infection, whether bacterial, fungal or other organisms. It has been shown that wounds contaminated with bacteria are more likely to cause melanosis (Sotiraki et al., 2010). as some bacterial types are distinguished, including: Proteus mirabilis ,Pseudomonas auroginosa ,Klebsiella spp, Streptococcus pyogenes ,Enterobacter faecalis ,E. Coli. In addition to Staphylococcus aureus, its ability to produce volatile organic compounds that are considered as catalysts for flies, especially sulfur compounds (Kotze and Eloff, 2002). Female of myiasis flies attracted to the smell of infected wounds in animals and decomposed the organic materials and lay their eggs, these eggs hatch into larvae and the voracious larvae consume the tissues and decay It penetrates into healthy tissues causing deep injury. (Chaudhury et al., 2010). The infection is rare in humans, however, 165 human cases of myeloma were recorded from 1914 to 2014 (Singh and Singh, 2015). The causative factors of myiasis, such as low socioeconomic status, poor hygiene, people with mental illness, drug addicts, and patients with no health care, the myiasis pathogenesis caused death due to septicemia without apparent any symptoms. The first reported case of wound dressing of Lucilia sericata larvae in Korea was previously reported (Cho et al., 1999). The researchers reached the amplitude of the spread of myiasis in humans and animals in India, as 5 cases of wound necrosis were recorded, 2 in humans and 3 in cows, and all cases were infected with Chrysomya bezziana larvae. A case of auditory torsion of a 10-year-old girl in India with Chrysomya megacephala larvae reported (Singh et al., 1993). (Yaghoobi et al., 2005) reported a case of aural sedation in southern Iran with larvae of the green hero fly Lucilia sericata. The case of Lucilia sericata larvae was recorded in a 26-year-old man who was addicted to drugs. In Turkey, a case of auditory worsening of Wohlfuhrtia mangifica larvae, which affected a group of children suffering from chronic otitis (Yuca et al., 2005), was recorded. In Iraq, specifically in Basra governorate, two cases of cutaneous spiral fly larvae were recorded for two girls, aged eight and four, due to a head lice bite that stimulated the female to lay her eggs on the small amount of blood and then grow into larvae that feed inside the scalp (Al-Rubiay, 1998), while the reported cases in animals were 8 of traumatic myiasis in 2006 and one case in 2009, the results indicate that the infection rate in sheep is the highest percentage in terms of the veterinary recipients compared to other animals in Iraq (Okaily et al., 2016).

There is a type of myiasis in hospitals that lack hygiene called Noscomial myiasis or Noscomial infection which found in patients with skin ulcers, blisters or open wounds, recorded in diabetics, the weak and the elderly as a result of negligence hospital for the patients in terms of the smell of blood decomposed, cotton contaminated with blood and pus (John and Petri, 2006). The families Calliphoridae and Sarcophagidae were used to know the time of death of a person through the different stages of lineage development by taking the oldest larva present in the corpse and counting backwards to obtain the youngest larvae, which gives a rough estimate of death (Lord and Goff, 2003). 
This article provides information on myiasis flies and their relationship of some bacterial species to the occurrence of infection effects this disease causes on humans and animals due to the economic and health, and intensifying efforts to control these insects.

\section{Mystic classification}

There are two methods of classifying myiasis:

Ecological (Biological or Parasitological) method. This method depends on the relationship of the parasite to the host (Hall and Wall, 1995), The parasite's relation with the host is of two types: 1- specific myiasis, this type is divided into two types. A) obligatory parasitism, as the flies choose living organs or tissues only to lay their eggs or larvae. For example the forced flies as: Wöhlfartia magnifica, W. vigil (Flesh flies), Oestrus ovis (Sheep bot fly), Gasterophilus intestinalis (Horse bot fly), Hypoderma bovis (Warble fly), Dermatobia hominis (Human bot fly or the Torsalo), Chrysomya bezziana (Old- world screw-worm) (Kenawy, 2008).

B) Facultative parasitism: Where flies lay their eggs or larvae on living and dead tissues in three levels, the primary level when the larvae are able to start to myiasis and the secondary and tertiary levels when the host nears death. Flies attack sore and rotting wounds, as they are attracted to foul odors, as for clean wounds and healthy skin, flies cannot attack them. An example of selective flies parasitism is Lucilia spp. (Greenbottle flies, Calliphora spp. (Bluebottle flies), Sarcophaga spp. (Flesh flies), Piophila casei (Cheese skipper), and Tubifera tenax (Rat-tailed maggot) (Wall and Shearer, 1997). C- Accidental myiasis: where infection occurs to humans and animals by accident, by eating insect eggs or larvae with contaminated drink or food (Nagakura et al., 1991).

Anatomical classification of myiasis This method is based on affected parts of the host's body, which was first proposed by Bishop in 1922 and this method was modified by James in 1947 and then by Zumpt in 1965 (Gour et al., 2017). Among the types of myiasis, depending on the anatomical method:

* Sanguinivorous Myiasis: For example are flies that cause hemophilia Auchmeromyia luteola (Congo floor maggot) (Calliphoridae), Chrysomya bezziana and Dermatobia hominis (Oestridae), where the flies larvae have a voracious or insatiable behavior the blood. They are exo parasites that cause myiasis of the forced type. (Dutta et al., 2015).

*Cutaneous (Wound, Traumatic, dermal or sub-dermal) Myiasis: which is the most common type of myiasis (Visciarelli et al.,2007). The fly larvae feed on animal tissues (the epidermis and subcutaneous layer), which are affected by shocks or wounds as the flies are attracted by The obligatory as well as the facultative parasitism and the flies that cause myiasis are followed two families: Sarcophagidae and Calliphoridae like, Cochliomyia hominivorax, Lucilia sericata and Wohlfahrtia magnifica (Gour et al., 2017).

*Furuncular (Warble) Myiasis: is one of the types of skin myiasis and occurs as a result of the fly larvae penetrating into the healthy skin, causing a boil, abscess or nodule. The number of larvae per node varies according to the type of flies causing myiasis (Francesconi and Lupi, 2012). Severe itching, sensitivity, dermatitis, fluid leakage from the nodes, and nocturnal pain are symptoms of this type of myiasis (Mahal and Sperling, 
2012). Among the types of flies that cause this type of myiasis: Cuterebra sp., Cordylobia anthropophaga, Dermatobia hominis, Wohlfahrtia vigil and Wohlfahrtia magnifica (Robbins and Khachemoune, 2010).

*Migratory (Creeping) Myiasis: this type of myiasis occurs when the larvae of the flies causing myiasis begin to migrate to a distant part of the host's skin, resulting in this migration of ulcerated epithelium, causing inflammation in the dermis layer (Gour et al., 2017). As a Hypoderma bovis (Cattle bot fly) and Gasterophilus intestinalis. Humans accidentally and unintentionally become infected with this type of myiasis, but the larvae of this type of flies cannot complete their life cycle in human skin (Royce et al., 1999). * Cavity Myiasis: This type of myiasis includes infection of the body cavity by dipterous larvae. This type usually takes its name from the anatomically affected area (Francesconi and Lupi, 2012).

* Ocular (Ophthalmic) Myiasis: This type of myiasis occurs when the bipedal larvae invade the eye area of the host. The injury to the eye can be external, internal or orbital part. The injury can be exo, endo or orpital part of eye. Usually one larva is present inside the eye while 2-3 larvae have been recorded in the same eye (Jakobs et al., 1997). As for the eye injury from the outside, it is limited to the superficial tissue injury of the eye (Verstrynge and Foets, 2004) and the symptoms of this type of myiasis are redness of the eyes, pain in the eye area, loss of vision (Georgalas et al., 2011). An example is the flies that cause ocular myiasis: Cuterbera spp., Chrysomya bezziana, Dermatobia hominis and Lucilia spp. (Francesconi and Lupi, 2012).

*Oral Myiasis: was first described in 1909 and then described by Laurence in 1959. Oral nausea is linked to lack of oral hygiene (Lata et al., 1996), alcoholism, aging, bad breath, mental retardation, and other clinical forms such as gum disease (Hassona et al., 2014), (Gealh et al., 2009). People who have a long opening of the mouth are at risk of developing oral myiasis (Sharma et al.,2008). Among the symptoms of oral myiasis is swelling of the mouth, lips and gums with pain and a feeling of movement of larvae inside the mouth (Kamboj et al., 2007). Examples of flies that cause oral myiasis: Wohlfahrtia magnifica, Cochliomyia hominivorax, Musca domestica, Calliphora vicina and Chrysomya bezziana (Hassona et al., 2014).

* Aural (Otom) Myiasis: Includes the injury of the outer ear or the middle ear with twowinged larvae, where the adult female lays her eggs or larvae around the ear cavity and that the widening of the outer ear canal helps to lay eggs or larvae (Uzum et al., 2004). Although this type of myiasis is considered rare, $86.16 \%$ of 94 cases were recorded in a study conducted (Singh et al., 1993). This type of myiasis has been reported in children under 10 years of age as well as in vulnerable individuals (Casanova et. al., 2010). Among the symptoms of this type of myiasis are itching, otitis media, pain in the ear, dizziness, poor hearing, bad smell from the ear, perforation of the tympanic membrane, bleeding from the ear (Werminghaus et al., 2008). the best example of flies that cause auditory myiasis: Chrysomya bezziana, Wohlfahrtia magnifica, Cochliomyia hominivorax and Chrysomya megacephala (Francesconi and Lupi, 2012).

* Nasal myiasis: This type of myiasis occurs when female flies that cause myiasis lay their eggs or larvae directly into the nasal cavity or in the vicinity of it while the host 
sleeps (Aydin et al., 2006). 70-75\% of nasal myiasis was recorded in one study of myiasis (Arora et al., 2009), and in another study $11.7 \%$ of nasal myiasis was recorded in children (Singh et al., 1993).). Of the total of 252 patients with nasal angiosis, the percentage of patients older than 50 years reached $41.26 \%$, and the reason was due to the low standard of living and lack of hygiene, and most of the cases were recorded in people suffering from atrophic rhinitis as out of 252 cases $97 \%$ were suffering from atrophic rhinitis ( Arora et al., 2009). Patients with leprosy are more likely to have this type of myiasis, due to the loss of the ability to involuntarily sneeze, as well as ulcers and infection with atrophic rhinitis, in addition to the inability of patients to clean the nose properly due to deformities of the hands (Thami et al., 1995). Examples of flies that cause nosebleeds: Lucilia sericata, Oestrus ovis, Cochliomyia hominivorax, Chrysomya bezziana, Cephalopina titillator (Camel bot fly), Wohlfahrtia magnifica and Drosophila melanogaster (Francesconi and Lupi, 2012).

*Intestinal (Enteric) Myiasis: is a type of pseudomembranous myiasis, which is associated with the ingestion of food or water contaminated with fly larvae. The reason for the outbreak of this disease is poor socio-economic status, lack of hygiene, and contamination of water and food with fly larvae (Kun et al.,1998). This type of myiasis is more common in animals than in humans, as the fly larvae take the alimentary canal of mammals from the pharynx to the outlet opening as a shelter and shelter for them. Any patient who sleeps with his mouth open is vulnerable to this disease, especially patients who are comatose or who suffer from mental illnesses. The disease varies from non-symptomatic cases, where the infection is determined by the presence of larvae in the stool of the infected persons to abdominal pain, nausea, vomiting, anal itching or rectal bleeding (Karabiber et al., 2010). The symptoms may be confusing and confusing due to the presence of other parasites such as the Ascaris worm (fuentes Gonzalez and Risco Oliva, 2009). An example of the flies that cause intestinal myiasis is Gasterophilus intestinalis (Singh and Singh, 2015).

* Urinogenital myiasis: This type of myiasis affects the urinary and reproductive system of females and males by the larvae of flies and it will be classified according to its anatomical location into two types of exo urogenital myiasis and internal genitourinary myiasis. Exo urogenital myiasis, which is similar to traumatic myiasis, affects more women than men, as lack of underwear, cervical cancer, urethral secretions, and sexually transmitted diseases (Wadhwa et al., 2006) are all distinct factors that made the host vulnerable to myiasis. The external genitourinary system affecting the clitoris, vulva, and urethra (Kudur et al., 2010). In males, the reported cases affected the penis and the cyst of the testicles and urethra, causing itching and pain in the area around the urethra (Saleh and El Sibae, 1993). 2. Endo urogenital myiasis, which is rare, occurs when larvae reach the internal genital organs, causing dysuria, and upon examination of the urine, albumin and leukocytes were seen upon examination of the urine (Wadhwa $e t$ al., 2006). Examples of flies that cause urogenital myiasis: Sarcophaga haemorrhoidalis, Wohlfahrtia magnifica, Fannia canicularis and Sarcophaga carnaria (Francesconi and Lupi, 2012). 
* Cerebral Myiasis: This type of myiasis is rare, fatal, and the survival rates are low. Nevertheless, 9 confirmed cases have been recorded, (Cheshier et al., 2007) in the front lobes of skull and causes high blood pressure with ascites. Head, impaired mind, and motor impairment (Francios et al., 1987). Examples of flies that cause myiasm are Hypoderma bovis and Hypoderma lineatum (Francesconi and Lupi, 2012).

Diptera order currently includes more than 150,000 species of 10,000 genera belonging to 150 families. About 13 families include all the myostatic flies, are: Calliphoridae, Oestridae, Sarcophagidae, „Muscidae, Gastrophilidae, Phoridae, Drosophilidae, Psychodidae ,Stratiomydae, Scenopinidae, Syrphidae 'Piophilidae and Dryomyzidae (Singh and Singh, 2015).

Three families from the above families are the main causesd of myiasis, and they are:

1. Oestridae; Contains 151 species belonging to 28 genera, and all their species are obligate parasitism.

2. Sarcophagidae; Includes 2000 subspecies of 400 genera

3. Calliphoridae; It is one of the most common families of the Diptera order contain 150 genera and about 1000 species. Some species of this family can be distinguished by the insect's metallic, green or blue body, while some other species are not clear. Members of this family perform many environmental services, including decomposition of dead animal bodies, assisting in the pollination process.

\section{Some examples of flies that cause sedation}

Dermatobia hominis (human skin nap fly): This fly is of a large type, its length is about $12 \mathrm{~mm}$, the chest area is blue to gray in color, while the abdomen area is short and broad, bright blue in color and has feathery arches, spread in the forests of Mexico, Central and South America, and the adults do not feed, but they get their needs from the stored food during the larval age. The insect attaches its eggs to one side of the body of any flying insect that visits the human or animal, such as the Stomoxys fly or the mosquito of the genus Psorophora. Caused by the mosquito while it is feeding, it settles under the skin in the tissues and feeds on blood, causing swelling with an opening through which the larvae breathe, causing severe pain to the infected host. The investigated of this insect is in the head, arms, armpits, thigh and buttocks, infects humans, dogs, cattle and birds. The larval stage period 5-10 weeks as it becomes $25 \mathrm{~mm}$ in length and the first larval instar the body of the larva carries thorns arranged in two dorsal rows and one abdominal row, the second instar larvae have a pear shape and for the third instar larvae ovoid and has stomata. Respiratory area as emerging from the mouth with hooks, then develop to pupal in soil. The life cycle of the insect takes 3-4 months (Zammarchi et al., 2014). Fig. (1). 

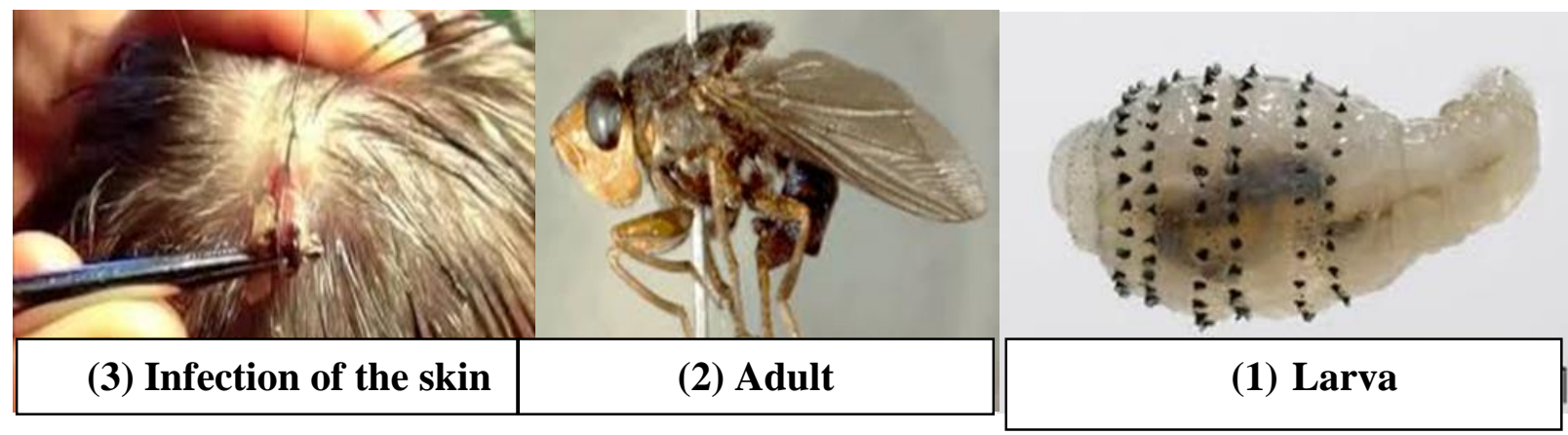

Fig. (1): Dermatobia hominis fly (Villalobos et al.,2016) (1) Larva of Dermatobia hominis fly (2) Adult of Dermatobia hominis fly (3) infecting human skin

Cordylobia anthrophaga (tambu fly): This insect belongs to the family of Calliphoridae and spreads in regions of Africa. Flies female started with laying of eggs in the soil contaminated with feces and urine, and the larva remains in the sand and upon the passage of the host of mammals, as humans, the larva attaches to host and penetrates the skin and grows formed bean-shaped bulge inside the host's skin with an opening in the middle through which the larva breathes through the respiratory stomata (Royce et al., 1999) The growth of the larva and its increase in size leads to the enlargement of the swelling (the seed) and the exit of copious secretions from the wound, the larval ages need 8 days to be completed and Then they fall into the soil to turn into a virgin (Jakobs et al., 1997) Fig. (2).
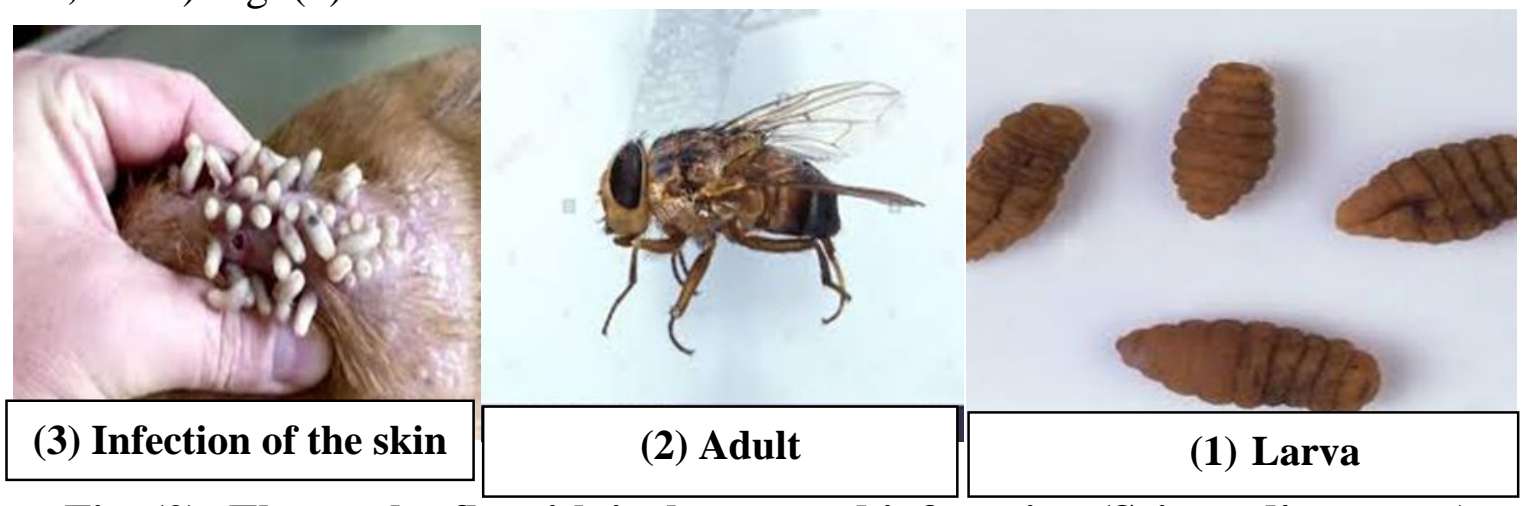

Fig. (2): The tambu fly with its larvae and infestation (Sciencedirect.com) $\begin{array}{lll}\text { (1) Larva of tambu fly } & \text { (2) Adult of tambu fly }\end{array}$ (2) infection of the skin

Calliphora hominivorax (spiral fly in the New World): It is larger than the domestic fly with a metallic bluish-green color, the face has a yellowish-orange color, Antenna from feathery shape. large respiratory stomata, and the body of larva is surrounded by spines in the form of wide ribbons, giving the larvae a wavy outline, and that is why it was called screw worms. This insect is found in North America and Brazil and attacks humans, and untreated infections lead to death. Its life cycle begins with the female 
laying the eggs on the edges of the wounds, on the blood secretions, and on the reproductive openings of the animals. The eggs hatch to collect the larvae and feed on the wounds (Erdmann, 1987) Fig.(3).

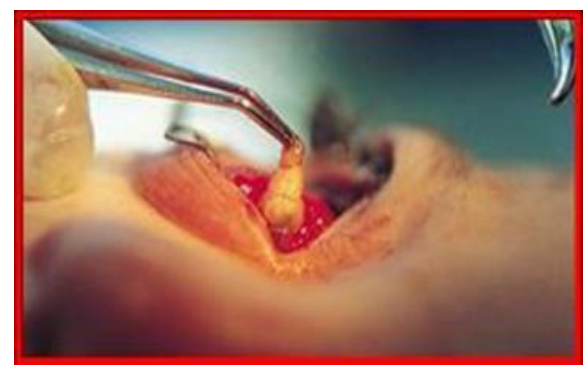

(3) Infection
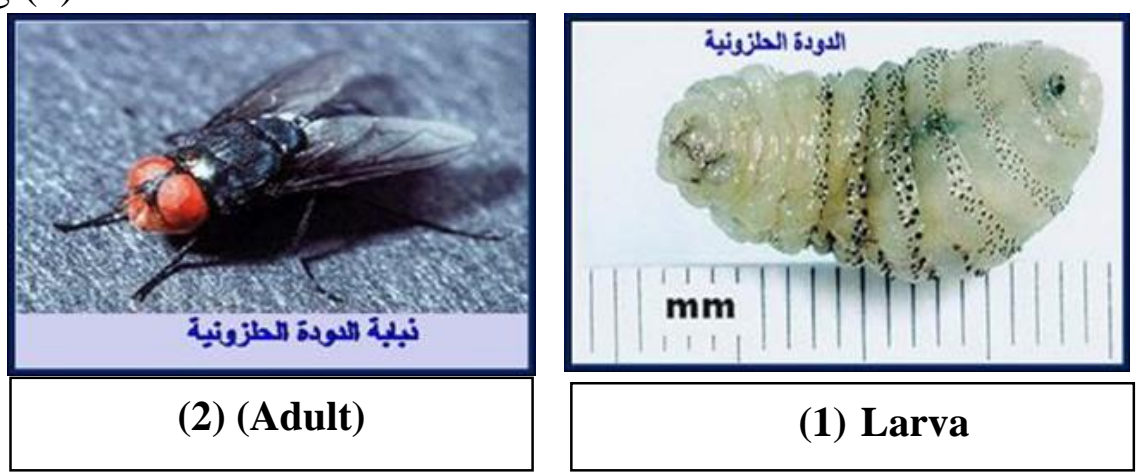

Fig. (3): The screwworm fly, its larvae and its presence in the wound (Figarola et al., 2001)

(1) Larva of The screwworm fly (2) Adult of The screwworm fly

(3) infection of the wound

Gastrophilus intestinal (horses stomach nodding): This insect belongs to the Gastrophilidae family, which is anobligatory parasites. The insect has a length of $18 \mathrm{~mm}$ and resembles a honey bee. This insect is found in many regions of the continents of Asia and Africa. Its life cycle begins with the female laying eggs on the animal's hair in the neck, mouth, head and front legs, and when the animal licks some parts of the front body through the tongue, the larvae attach to the tongue and enter the stomach and remain attached to its mucous membrane, and after nine months to a year the larvae come out with animal feces and the larvae turn to virgins in the soil and after a while the virgins turn into adults and the cycle begins again (Atia et al.,2018) Fig. (4).
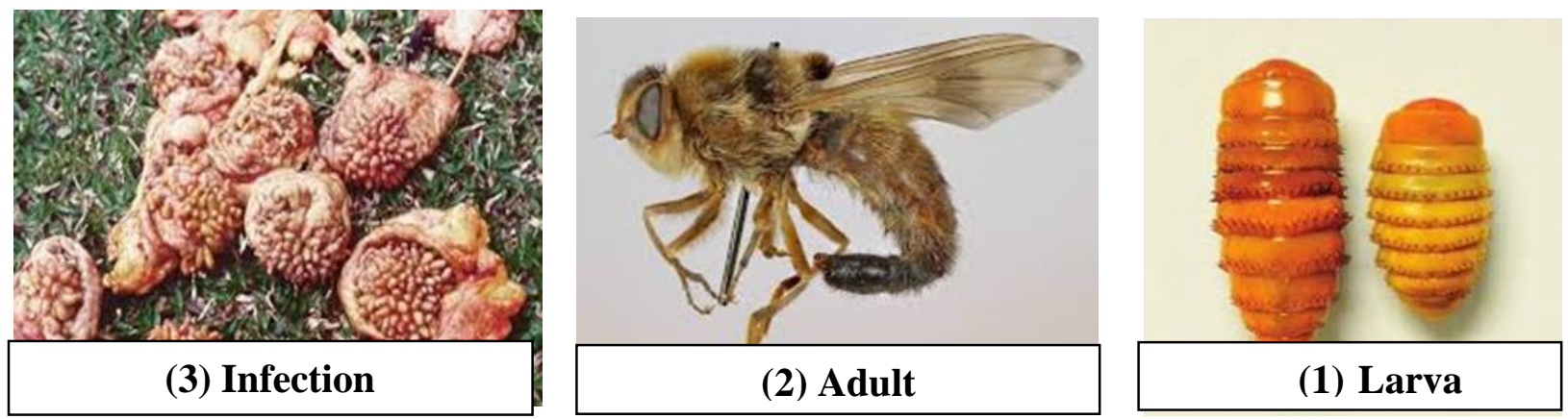

Fig. (4): Cows stomach fly with its larvae and infestation (Atia et al.,2018) (1) Larva of Cows stomach fly (2) Adult of Cows stomach fly (3) infection of the stomach

\section{Bacterial infections associated with myiasis}

Most of the wounds contaminated with different bacterial types are associated with myiasis. These bacterial types can spread and reach the blood stream causing blood 
poisoning and leading to the death of large numbers of livestock (Caballero et al., 1996). There are skin infections of cattle with staphylococcus, where species of flies belonging to the order of Diptera lay their eggs around the infected wounds in addition to the presence of bacterial species on the outer surface of the body of the insect that is considered a natural flora but when it enters the wounds it turns into opportunistic bacteria causing infections and stenosis of wounds, whether for humans or livestock and most The normal flora belongs to the genus Streptococcus spp. Staphylococcus aureus (Caballero et al., 1996). It is worth noting that the attraction of flies to wounds is due to the smells emitted from tissue decomposition by bacterial species that produce volatile organic compounds with distinctive odors. In a study of Zhu and collageus in 2017 (Zhu et al., 2017), five bacterial species were isolated from wounds infected with myiasis, and they were all due to Cram-negative bacteria, they analyzed the organic compounds present in the wounds that cause odors emitted from them using GC technology and observed that the phenolic compounds emitted from klebsiella peneumonia (Taylor and Kiene, 1989), cresol compounds emitted by Citrobacter freundii and dimethyle, dimethyl disulphide, and trisulphide compounds produced by Pseudomonas spp. Enterobacter spp. (Liu et al.,2016). These volatile compounds are produced from the bacterial metabolism, but in different proportions, as the synergistic bacterial species produce these volatile compounds in larger quantities than they do in isolation. The ability of the bacteria to attract insects is due to its ability to sense a quorum, including proteus mirabilis, as the strains belonging to this type produce substances that attract insects such as Phenyl Acetic Acid (PAA), Dimethyl disulphide (DMDS), Isobutyl amine (IBA) and Indole (IND), which is a secondary metabolite and derived from the amino acids phenylalanine, trptophan, methionine (Sasaki et al., 2010). These amino acids are essential for the reproduction of insects, as they are a signal for both females and males for the purpose of mating, indicating that smells are a source of warning for all ages of flies inside these wounds (Chukwu et al., 2012) where female flies that cause myiasis and carry eggs by placing them around wounds and hatching into larvae dig deep into the wounds and feed on tissues and body fluids in addition to contamination with positive and negative bacterial species for the cream dye, which is the main source of volatile organic compounds and causes odors that attract female flies that cause myiasis (Parker and Welch, 1992).

Moreover, these insects are considered one of the most important disease vectors for humans and animals because they carry germs on their outer surface or some parasites live inside them, such as the parasite that transmits malaria, and there are many studies in this regard to find out the relationship between insects and bacteria in the events of myiasis, as in a study of Caballero and others 1996, when they wrer able to isolate several bacterial types from sheep affected by myiasis caused by flies from the type Cochliomyia hominvorax, and he observed the dominance of the Gram-negative bacterial species, including E. coli, Proteus spp., Proteus mirabilis compared to the positive types of Staphylococcus aureus with doveloment of infection. In another study conducted by Chukwa and others in 2012, which was conducted on pets, including dogs with cutaneous myiasis caused by Cordylobia anthropophase flies associated with infection 
with other bacterial species, including Staphylococcus aureus, E.coli and Corynebacteria spp.

\title{
Flies control
}

The first way in the control is to prevent and assist in eradicating the fly larvae before they can cause any harm, and it is called controlling the cause. The second method of control is to treat as soon as the injury occurs and take care of the injured person or animal.

\section{preventation}

It includes the use of pesticides in the environment in which agricultural animals are raised. Organic phosphorous compounds or organic chlorine compounds may be used in spraying operations. One of the methods is also to eradicate the causative flies by using the sterilization method for artificially raised male flies, and then release them into the environment. The sterilized males compete with the fertile males that are naturally present in the environment to mate and fertilize the natural females, which leads to the laying of the natural females inoculated with the sterilized males with an unfertilized egg so that the eggs do not hatch and thus do not grow into larvae. To prevent circulating in humans, general hygiene and personal hygiene must be improved by washing clothes well in hot water and drying them away from flies, and ironing clothes well after drying to kill eggs and larvae, as the heat of the iron kills the eggs of flies (Zhu et al., 2017).

\section{Treatment}

The treatment is done as soon as the worm has formed the ventilation hole by covering the hole with a thick covering with Vaseline, which causes cutting off the oxygen to the larvae, forcing them to exit from under the skin to the surface, making it easier to deal. The fastest treatment option is to incise the wound and extract the larvae by applying pressure around the site of infection, and then clean and disinfect the wound (Zhu et al., 2017).

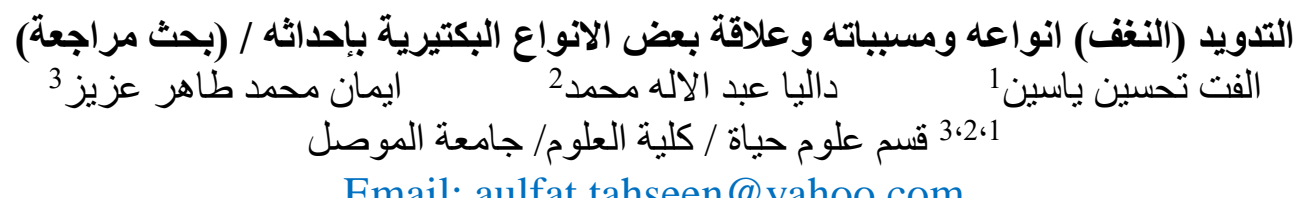

Email: aulfat.tahseen@yahoo.com

\begin{abstract}
الخلاصة
النغف Myiasis من اكثر العلاقات المعقدة والمثيرة للاهنمام التي نشاهدها في الطبيعة اذ يمثل العلاقة بين

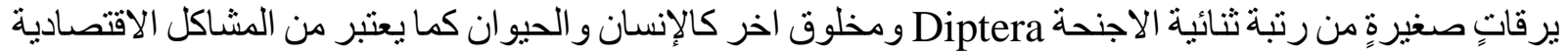

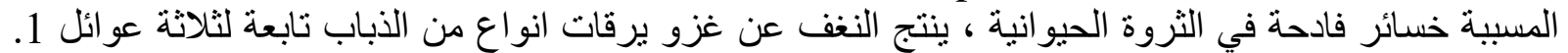
عائلة النبريات Oestridae لأنسجة واعضاء جسم الانسان و الحيوان على حد سواء حيث تتغذى هذه اليرقات على الانسجة الحية و الميتة ، كما

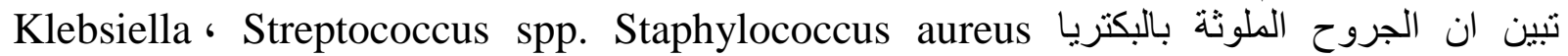
Proteus mirabilis و Enterobacter spp. ، Pseudomonas spp. 'peneumonia, الاصابة بالنغف نتيجة لقدرتها على اتتاج مركبات عضوية متطايرة تعتبر كمحفزات للذباب ـ لذا ارتأينا في هذه
\end{abstract}




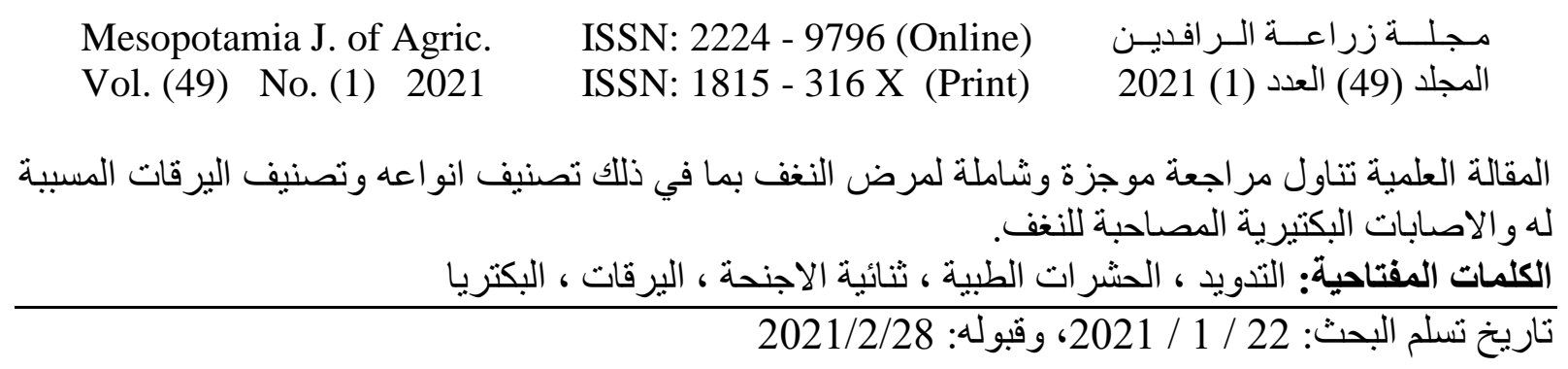

\section{REFERENCES}

Al-Rubiay, K.K. (1998). Human cutaneous myiasis: a report of two case associated with head lice caused by chrysomya bezziana (Diptera: calliphoridae) Basrah Journal of Science, 16(2),23-26.

Arora, S., Sharma, J. K., Pippal, S. K., Sethi, Y., \& Yadav, A. (2009). Clinical etiology of myiasis in ENT: a reterograde period-interval study. Brazilian Journal of Otorhinolaryngology, 75(3), 356-361.

Attia, M. M., Khalifa, M. M., \& Mahdy, O. A. (2018). The prevalence of Gasterophilus intestinalis (Diptera: Oestridae) in donkeys (Equus asinus) in Egypt with special reference to larvicidal effects of neem seed oil extract (Azadirachta indica) on third stage larvae. Open veterinary journal, 8(4), 423-431.

Aydin, E., Uysal, S., Akkuzu, B., \& Can, F. (2006). Nasal myiasis by fruit fly larvae: a case report. European Archives of Oto-Rhino-Laryngology and Head \& Neck, 263(12), 1142-1143.

Braverman, I., Dano, I., Saah, D., \& Gapany, B. (1994). Aural myiasis caused by flesh fly larva, Sarcophaga haemorrhoidalis. The Journal of otolaryngology, 23(3), 204-205.

Caballero, M., Hernandez, G., Poudevigne, F., \& Ruiz-Martinez, I. (1996). Isolation and identification of bacteria associated with the screwworm fly Cochliomyia hominivorax, coquerel and its myiasis. Annals of the New York Academy of Sciences, 791, 248-254.

Casanova-Román, M., Sánchez-Legaza, E., Sanchez-Porto, A., \& Murga, C. (2010). Aural myiasis in an infant. Infez Med, 18(03), 175-176.

Chaudhury, M. F., Skoda, S. R., Sagel, A., \& Welch, J. B. (2010). Volatiles emitted from eight wound-isolated bacteria differentially attract gravid screwworms (Diptera: Calliphoridae) to oviposit. Journal of Medical Entomology, 47(3), 349-354.

Cheshier, S. H., Bababeygy, S. R., Higgins, D., Parsonnet, J., \& Huhn, S. L. (2007). Cerebral myiasis associated with angiosarcoma of the scalp: case report. Neurosurgery, 61(1), E167-E167.

Cho, J. H., Kim, H. B., Cho, C. S., Huh, S., \& Ree, H. I. (1999). An aural myiasis case in a 54-year-old male farmer in Korea. The Korean journal of parasitology, 37(1), 51-53.

Chukwu, C. O., Ogo, N. I., Jimoh, A., \& Chukwu, D. I. (2012). Pathogenic bacteria associated with cutaneous canine myiasis due to Cordylobia anthropophaga. Veterinary World, 5(10),617-620. 
Dutta, T. C., Islam, S., Bam, J., \& Pathak, P. (2015). Transboundary Sanguinivorous Myiasis due to an Oriental Auchmeromyia sps. in a Domesticated Pig. Indian Vet. $J$, 92(12), 68-69.

Erdmann, G. R. (1987). Antibacterial action of myiasis-causing flies. Parasitology Today, 3(7), 214-216.

Figarola, J. L., Skoda, S. R., Berkebile, D. R., \& Foster, J. E. (2001). Identification of screwworms, Cochliomyia hominivorax (Coquerel)(Diptera: Calliphoridae), with a monoclonal antibody-based enzyme-linked immunosorbent assay (MAbELISA). Veterinary Parasitology, 102(4), 341-354.

Francesconi, F., \& Lupi, O. (2012). Myiasis. Clinical microbiology reviews, 25(1), 79105.

Francois, P., Martin, G., Goullier, A., Plasse, M., \& Beaudoing, A. (1987). Neuromeningeal hypodermyiasis complicated by hydrocephaly. Value of nuclear magnetic resonance imaging. Presse medicale (Paris, France: 1983), 16(25), 1231-1233.

Fuentes González, O., \& Risco Oliva, G. (2009). First report of intestinal myiasis caused by Hermetia illucens (Diptera: Stratiomyidae). Revista Cubana de Medicina Tropical, 61(1), 97-99.

Gealh, W. C., Ferreira, G. M., Farah, G. J., Teodoro, U., \& Camarini, E. T. (2009). Treatment of oral myiasis caused by Cochliomyia hominivorax: two cases treated with ivermectin. British Journal of Oral and Maxillofacial Surgery, 47(1), 23-26.

Georgalas, I., Ladas, I., Maselos, S., Lymperopoulos, K., \& Markomichelakis, N. (2011). Intraocular safari: ophthalmomyiasis interna. Clinical \& experimental ophthalmology, 39(1), 84-85.

Gour, S., Kumar, V., Thapliyal, G. K., \& Nalin, N. (2017). An update on cutaneous myiasis: A review. Rev. Artic. Saudi J. Oral Dent. Res, 2, 31-37..

Hall, M. J., Wall, R. L., \& Stevens, J. R. (2016). Traumatic myiasis: a neglected disease in a changing world. Annual Review of Entomology, 61, 159-176.

Hall, M., \& Wall, R. (1995). Myiasis of humans and domestic animals. Advances in parasitology, 35, 257-334.

Hassona, Y., Scully, C., Aguida, M., \& de Almeida, O. P. (2014). Flies and the mouth. Journal of investigative and clinical dentistry, 5(2), 98-103.

Jakobs, E. M., Adelberg, D. A., Lewis, J. M., Trpis, M., \& Green, W. R. (1997). Ophthalmomyiasis interna posterior. Report of a case with optic atrophy. Retina (Philadelphia, Pa.), 17(4), 310-314.

John, D. T., \& Petri Jr, W. A. (2006). Markell and Voge's medical parasitology. 9th. Ed. St. Louis, Missouri: Saunders Elsevier, 178-81.

Kamboj, M., Mahajan, S., \& Boaz, K. (2007). Oral myiasis misinterpreted as salivary gland adenoma. Journal of clinical pathology, 60(7), 848-848.

Karabiber, H., Oguzkurt, D. G., Dogan, D. G., Aktas, M., \& Selimoglu, M. A. (2010). An unusual cause of rectal bleeding: intestinal myiasis. Journal of pediatric gastroenterology and nutrition, 51(4), 530-531. 
Kenawy, M.A. (2008). Medical and Veterinary Entomology. Lectures' Note, Entomology Department, Faculty of Science, Shams University, Cairo, Egypt. : 122.

Kotze, M., Eloff, J. N., \& Houghton, P. J. (2002). Extraction of antibacterial compounds from Combretum microphyllum (Combretaceae). South African Journal of Botany, 68(1), 62-67.

Kudur, M. H., Pooja, M., \& Nayak, S. (2010). Unusual presentation of cutaneous myiasis. Indian Journal of Dermatology, Venereology, and Leprology, 76(6),712-716.

Kun, M., Kreiter, A., \& Semenas, L. (1998). Myiasis gastrointestinal humana por Eristalis tenax. Revista de Saude Publica, 32, 367-369.

Lata, J., Kapila, B. K., \& Aggarwal, P. (1996). Oral myiasis: a case report. International journal of oral and maxillofacial surgery, 25(6), 455-456.

Liu, W., Longnecker, M., Tarone, A. M., \& Tomberlin, J. K. (2016). Responses of Lucilia sericata (Diptera: Calliphoridae) to compounds from microbial decomposition of larval resources. Animal Behaviour, 115, 217-225.

Lord, W. D., \& Goff, M. L. (2003). Forensic Entomology: Application of Entomological Methods to The Investigation of Death. Handbook of Forensic Pathology, 2nd Edn, College of American Pathologists, Illinois. : 423-436.

Luseba, D., Elgorashi, E. E., Ntloedibe, D. T., \& Van Staden, J. (2007). Antibacterial, anti-inflammatory and mutagenic effects of some medicinal plants used in South Africa for the treatment of wounds and retained placenta in livestock. South African Journal of Botany, 73(3), 378-383.

Mahal, J. J., \& Sperling, J. D. (2012). Furuncular myiasis from Dermatobia hominus: a case of human botfly infestation. The Journal of emergency medicine, 43(4), 618621.

Nagakura, K., Kawauichi-Kato, Y., Thchibana, H., Kaneda, Y., Shinonaga, S., \& Kano, R. (1991). Three cases of intestinal myiasis in Japan. Journal of Infectious Diseases, 163(5), 1170-1171..

Okaily, R., Mohammed, A., Hamad, B. and Abass, A. (2016). The annual infection by larvae of fly's that causing traumatic myiasis in Babylon province. Kufa Journal For Veterinary Medical Sciences. 7(1):26-30

Parker, F. D., \& Welch, J. B. (1992). Monitoring adult populations of the screwworm (Diptera: Calliphoridae) with feeding stations baited with liver. Journal of economic entomology, 85(5), 1740-1753.

Robbins, K., \& Khachemoune, A. (2010). Cutaneous myiasis: a review of the common types of myiasis. International journal of dermatology, 49(10), 1092-1098.

Royce, L. A., Rossignol, P. A., Kubitz, M. L., \& Burton, F. R. (1999). Recovery of a second instar Gasterophilus larva in a human infant: a case report. The American journal of tropical medicine and hygiene, 60(3), 403-404.

Saleh, M. S., \& El Sibae, M. M. (1993). Urino-genital myiasis due to Piophila casei. Journal of the Egyptian Society of Parasitology, 23(3), 737-739. 
Sasaki-Imamura, T., Yano, A., \& Yoshida, Y. (2010). Production of indole from Ltryptophan and effects of these compounds on biofilm formation by Fusobacterium nucleatum ATCC 25586. Applied and environmental microbiology, 76(13), 4260-4268..

Sharma, J., Mamatha, G. P., \& Acharya, R. (2008). Primary oral myiasis: A case report. Standard Journal Abbreviation (ISO4) Medicina Oral, Patologia Oral y Cirugia Bucal 13: $714-716$.

Singh, A., \& Singh, Z. (2015). Incidence of myiasis among humans-a review. Parasitology research, 114(9), 3183-3199.

Singh, I., Gathwala, G., Yadav, S. P. S., Wig, U., \& Jakhar, K. K. (1993). Myiasis in children: the Indian perspective. International journal of pediatric otorhinolaryngology, 25(1-3), 127-131.

Sotiraki, S., Farkas, R., \& Hall, M. J. R. (2010). Fleshflies in the flesh: epidemiology, population genetics and control of outbreaks of traumatic myiasis in the Mediterranean Basin. Veterinary parasitology, 174(1-2), 12-18.

Taylor, B. F., \& Kiene, R. P. (1989). Microbial metabolism of dimethyl sulfide. in Biogenic Sulfur in the Environment. ACS Symposium Series, 393: 202-221.

Thami, G. P., Baruah, M. C., Sharmce, S. C., \& Behera, N. K. (1995). Nasal myiasis in leprosy leading to unusual tissue destruction. The Journal of dermatology, 22(5), 348-350.

Uzun, L., Cinar, F., Beder, L. B., Aslan, T., \& Altintas, K. (2004). Radical mastoidectomy cavity myiasis caused by Wohlfahrtia magnifica. The Journal of laryngology and otology, 118(1), 54.Verstrynge, K., Foets, B., (2004). External ophthalmomyiasis: a case report. The Bulletin of the Belgian Society of Ophthalmology ,:67-71.

Verstrynge, K., \& Foets, B. (2004). External ophthalmomyiasis: a case report. Bulletin de la Société belge d'ophtalmologie, 294, 67-71.

Villalobos, G., Vega-Memije, M. E., Maravilla, P., \& Martinez-Hernandez, F. (2016). Myiasis caused by Dermatobia hominis: countries with increased risk for travelers going to neotropic areas. International journal of dermatology, 55(10), 1060-1068.

Visciarelli, E., Costamagna, S., Lucchi, L., \& Basabe, N. (2007). Miasis Humana en Bahía Blanca, Argentina: periodo 2000/2005. Neotropical entomology, 36(4), 605-611.

Wadhwa, V., Kharbanda, P., Rai, S., \& Uppal, B. (2006). Urogenital myiasis due to Chrysomyia bezziana. Indian journal of medical microbiology, 24(1), 70-71.

Wall, R., \& Shearer, D. (1997). The diagnosis and control of ectoparasite infestation. In Veterinary Entomology (pp. 313-401). Springer, Dordrecht.

Werminghaus, P., Hoffmann, T. K., Mehlhorn, H., \& Bas, M. (2008). Aural myiasis in a patient with Alzheimer's disease. European archives of oto-rhinolaryngology, 265(7), 851-853. 
Yaghoubi, R., Tirgari, S., \& Sina, N. (2005). Human Auricular Myiasis Caused By Lucilia Sericata: Clinical And Parasitological Considerations. Medica Iranica,43(2), 155-157.

Yuca, K., Çaksen, H., Sakin, Y. F., Yuca, S. A., Kiris, M., Yilmaz, H., \& Çankaya, H. (2005). Aural myiasis in children and literature review. The Tohoku journal of experimental medicine, 206(2), 125-130.

Zammarchi, L., Viligiardi, R., Strohmeyer, M., \& Bartoloni, A. (2014). Dermatobia hominis: Small migrants hidden in your skin. Annals of Dermatology, 26(5), 632637.

Zhu, J. J., Chaudhury, M. F., Durso, L. M., Sagel, A., Skoda, S. R., Jelvez-Serra, N. S., \& Santanab, E. G. (2017). Semiochemicals released from five bacteria identified from animal wounds infested by primary screwworms and their effects on fly behavioral activity. PLoS One, 12(6), e0179637090. 